\title{
Urine Color Analysis of Hydration Status in Employees Working in Bandung, Indonesia
}

\author{
Liza Karina Hauteas R. Sutono, ${ }^{1}$ Rudi Supriyadi, ${ }^{2}$ Yenni Zuhairini ${ }^{1}$ \\ ${ }^{1}$ Faculty of Medicine Universitas Padjadjaran, Indonesia, ${ }^{2}$ Department of Internal Medicine \\ Faculty of Medicine Universitas Padjadjaran/Dr. Hasan Sadikin General Hospital, Bandung, \\ Indonesia, ${ }^{3}$ Department of Public Health Faculty of Medicine Universitas Padjadjaran, Indonesia
}

\section{Abstract}

Background: Dehydration can be compensated for by the body. However, if it occurs persistently, it can cause concentration problems, thermoregulation disorders, kidney damage, and other lifethreatening disorders such as cardiovascular disorders. Urine color is a simple indicator to assess a person's hydration status. The purpose of this study was to explore the hydration status of employees working in Bandung, Indonesia.

Methods: This was a descriptive cross-sectional study conducted from March to November 2019. This study was a part of another study exploring urine color levels. Urine was collected on Sunday morning when the employees were free. Water intake and workload before urine examination were not taken into account. Hydration status was divided into three categories: well-hydrated, mild/moderate dehydration, and severe dehydration. A total sampling method was used to collect data.

Results: In total, 178 subjects who met the study criteria participated in the study. The majority of respondents were 40-79 years old, male, did not have hypertension or diabetes, and active smokers. Most respondents experienced severe dehydration (44.7\%) although $58.1 \%$ had consumed $\geq 8$ glasses of water/day.

Conclusions: More than half employees have consumed adequate amount of water; however, the majority are severely dehydrated when assessed based on their urine color. Further study on the balance of water intake and excretion is needed to explore the phenomenon of dehydration in the morning.

Keywords: Dehydration, hydration status, urine color

\section{Introduction}

Well-hydrated or normohydration is a condition where water intake and excretion are in balance. ${ }^{1}$ When the fluid balance in the body fails to be preserved, dehydration can occur, which is the process of fluid loss in the human body. One of the causes of dehydration is excessive sweating with insufficient water intake. ${ }^{1}$ Previous study conducted on workshop workers demonstrates a strong connection between fluid intake and hydration status. ${ }^{2} \mathrm{~A}$ group respondents considered to be at risk of dehydration is field workers because they work in a hot working environment among others under the sun exposure, and they spend a lot of energy while doing their work. Field workers also often do not pay attention to the balance of water intake and excretion.

Loss of fluid, approximately $1 \%$ of body weight, can usually be compensated within
24 hours by the body. It is characterized by increased thirst and urine concentration. If the process of fluid loss continues, the water volume in the blood will decrease and overall blood volume is decreased as well. As a result, the heart will have difficulty maintaining blood perfusion to other organs, leading to impaired cardiovascular function, which can be marked by a decrease in blood pressure and an increase in heart rate. Dehydration that occurs persistently can cause blood perfusion to the skin, kidney, or brain to decrease. Furthermore, it can cause disturbances in concentration, headaches, fatigue, reduced physical performance, impaired thermoregulatory function, kidney damage, and can be life-threatening. ${ }^{1,3}$

There are various ways to assess a hydration status, one of which is to observe the color of urine, which is simple, practical, fast, and inexpensive. This assessment has

Correspondence: Liza Karina Hauteas R. Sutono, Faculty of Medicine Universitas Padjadjaran, Jalan Raya Bandung-Sumedang Km. 21, Jatinangor, Sumedang, West Java- Indonesia, E-mail: lisakarinahauteas@gmail.com 
been validated, both in adults and children., ${ }^{4,5}$ One of the factors that can affect the urine color density is the amount of water that dissolves urine color compounds, which are urochrome, uroerythrin, and urobilin. The water amount in the urine in the dehydrated individuals will be lower than the urine color compounds, causing darker urine color. ${ }^{5,6}$ This study aimed to determine the hydration status variations by observing the color of urine among field workers in Bandung, for early detection of dehydration status, in order to further exploring the preventive action.

\section{Methods}

This research was a descriptive, crosssectional study, conducted from March to November 2019. The hydration status based on urine color analysis was determined among adult employees in Bandung. This study used the secondary data from a previous study. In brief, a questionnaire was distributed during the World Kidney Day 2019 event, held by Dr. Hasan Sadikin General Hospital in collaboration with the Indonesian Nephrology Association (Perhimpunan Nefrologi Indonesia, PERNEFRI). Urine was taken on a Sunday morning when the employees were free or not working. Their water intake and workload before the urine examination were not taken into account. The exclusion criteria were incomplete data on age, gender, amount of water intake per day, smoking status, or comorbid disease statuses such as hypertension and diabetes. After consent, the respondents filled out a questionnaire and collected their urine on a transparent tube for free urine examination. The result was consulted to the doctor present at the event. The urine obtained was then compared with the standard urine color chart, released by the Ministry of Health Republic of Indonesia (2018) by placing a white paper behind the tube, and therefore the urine color was more visible (Figure 1). There were eight colors of urine that was designated into level 1 to 8 , indicating the palest urine color to the darkest concentrated urine color, respectively. This level of urine color was pointing out to the hydration level that was categorized into well-hydrated (level 1-3), mild/moderate dehydration (level 4-5), and severe dehydration (level 6-8).

All respondents were given information about this study, and those who were willing to take part in this study were asked to sign an agreement form. This study had been approved by the Research Ethics Committee of Universitas Padjadjaran Bandung (No. 996/ UN6.KEP/EC/2019).

\section{Results}

In total, 178 data were obtained for this study, however, 73 data were incomplete and thus only 105 data were taken into further analysis. The characteristics of the employees showed that the majority was male $(80.95 \%)$ and aged

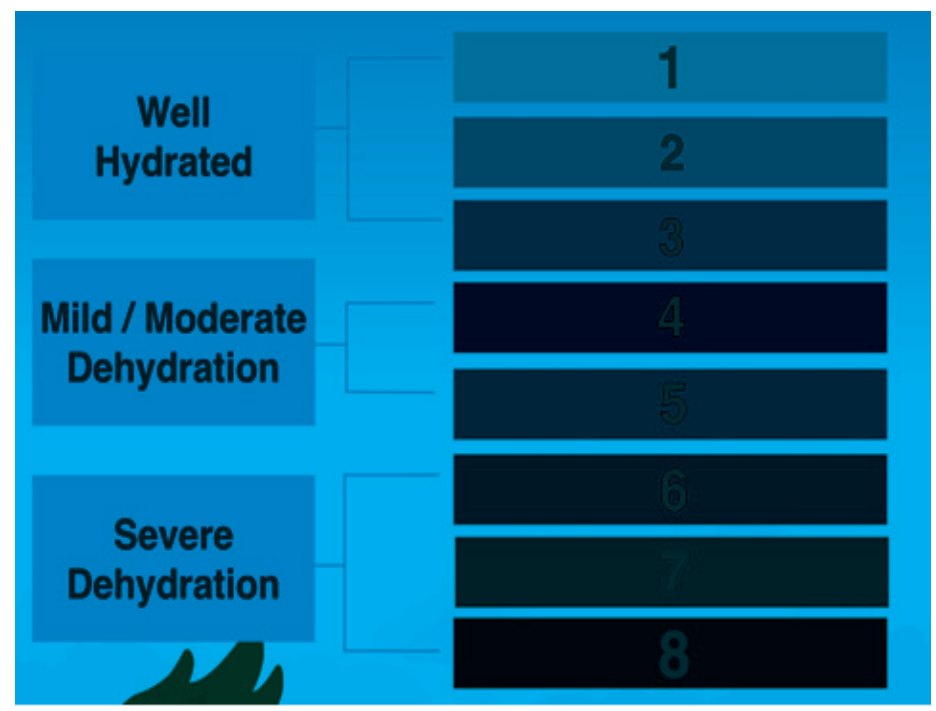

Figure 1 Standard Urine Color Chart ${ }^{7}$ 
Table 1 Characteristics of Employees

\begin{tabular}{lcc}
\hline Characteristic (n=105) & Frequency(n) & Percentage (\%) \\
\hline Age (year): & 50 & $47.62 \%$ \\
$19-39$ & 55 & $52.38 \%$ \\
$>40$ & & \\
Gender & 85 & $80.95 \%$ \\
Male & 20 & $19.05 \%$ \\
Female & & $10.48 \%$ \\
Hypertension & 11 & $89.52 \%$ \\
Yes & 94 & \\
No & & $2.86 \%$ \\
Diabetes & 3 & $97.14 \%$ \\
Yes & 102 & \\
No & & $50.48 \%$ \\
Smokers & 53 & $49.52 \%$ \\
Active & 52 & \\
Passive/Non-Smoker & $32 \%$ \\
\hline
\end{tabular}

$>40$ years old $(52.38 \%)$. Hypertension was detected in $10.48 \%$, diabetes in $2.86 \%$ and half of them were active smokers $(50.4 \%)$, as shown in Table 1.

The majority of employees were in severe dehydration (44.76\%), although the majority of subjects had consumed $\geq 8$ glasses of water per day (58.10\%) as shown in Table 2.

The hydration level based on water intake per day was shown in Figure 2, which illustrated the high number of respondents who were in mild/moderate and severe dehydration conditions despite consuming water $\geq 8$ cups per day (Figure 2). However, a T-test performed to reveal the significance of the relationship between hydration level with consumed water had shown no significant relationship between hydration level with the consumed water $(\mathrm{p}=0.059$, data not shown).

\section{Discussions}

The level of hydration has been divided into three categories; well/good hydration, mild/ moderate dehydration, and severe dehydration. The hydration has been based on age, gender, or whether there is a comorbid disease such as hypertension and diabetes, type of smokers, and how much water per day is consumed. The daily water intake is recommended as much as 8 cups or about $2-2.5$ liters per day. ${ }^{1,8}$ However,

Table 2 Hydration Level and Water Intake among employees in Bandung

\begin{tabular}{lcc}
\hline & Frequency (n) & Percentage (\%) \\
\hline Level of hydration & & 24.76 \\
Well-hydrated & 26 & 30.48 \\
Mild/moderate dehydration & 32 & 44.76 \\
Severe dehydration & 47 & \\
Water Intake (glass/day): & & 41.90 \\
$<8$ & 44 & 58.10 \\
$\quad \geq 8$ & 61 & \\
\hline Note: well-hydrated (level 1-3), mild/moderate dehydration (level 4-5) and severe dehydration (level 6-8).
\end{tabular}




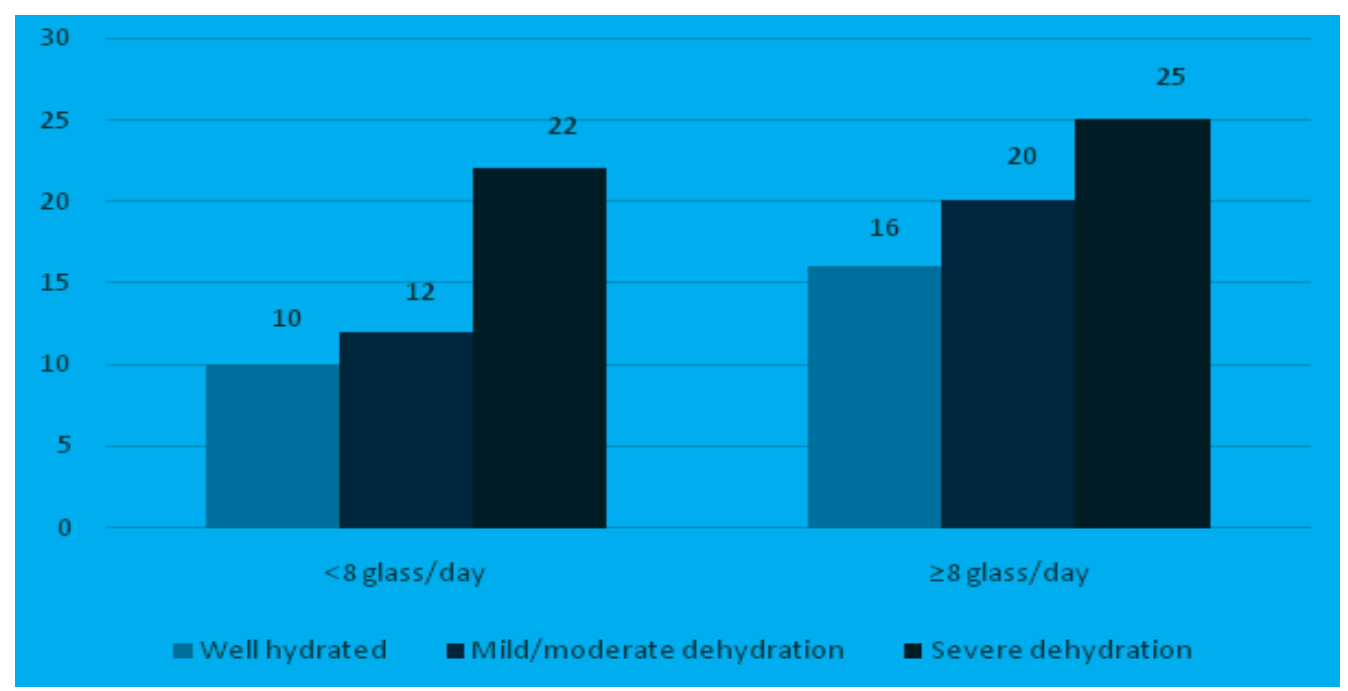

Figure 2 Hydration Level based on Daily Water Intake

this study shows that there is no significant relationship between daily consumed water with hydration level $(\mathrm{p}=0.059)$, although others reported a strong relationship. ${ }^{2}$ This different result might be caused by the study number. Further study is needed to explore this relationship.

Interestingly, the condition of mild/ moderate or severe dehydration is still high in individuals who have consumed 8 glasses of water per day (Figure 2). Dehydration usually occurs due to lack of water intake or when water excretion exceeds water intake, therefore, the urine will be concentrated and produce a darker color. ${ }^{6,9}$ Morning urine may have a darker color since there is a is lack of water intake at the previous night. The lack of water in the blood can reduce the blood plasma rate towards the kidneys, it can reduce the rate of renal filtration that will be detected by the kidneys. The kidneys will increase water reabsorption and only a small amount of water is excreted through urine. The body can detect the rise of water in the blood within 10 minutes after rehydration. ${ }^{9,10}$

Our study has shown that the highest percentage of severe dehydration are those among the aged range of 40-79, however, the majority have consumed more than 8 cups of water per day, as recommended by the Ministry of Health Republic of Indonesia. Kidney function will decrease through aging, and there will be changes in the structure and function of the kidneys, leading to a reduced number and size of the nephron. The change begins at the age of 20 years, which occurs progressively butslowly. The significant change might be detected at the age of 50 years. This study also reported that reduced renal ability to concentrate urine comes along with aging thus it can increase the risk of dehydration, 11 making this one of the factors that causes a large number of concentrated urine findings in the elderly individuals in the study.

The majority of our respondents were male and the largest percentage of severely dehydrated man has consumed more than 8 glasses of water per day. In opposite to this study, other study showed that dehydration is more common in women because women have more fat proportion in the body, thus, the water amount is lower. ${ }^{12}$ However, when associated with kidney aging, males produce consistently more concentrated urine than females. ${ }^{13}$ After the age of 40 years, the glomerular filtration rate (GFR) in males will decline by $1 \%$ per year, while in women GFR will remain stable until 50 years of age. ${ }^{14}$ This can be caused by the estrogen hormone that may provide a protective effect on the kidneys. Androgen hormones instead may have a negative effect on kidney aging. Estrogen can stimulate the synthesis of nitrite oxide (NO) which has a vasodilator effect on various blood vessels including the renal arteries. The vasodilator effect may improve the perfusion to kidney cells and it maintains kidney cell survival. Estrogen cans also the amount of angiotensin II and angiotensin-converting enzyme (ACE) and therefore reducing its activity, which is 
vasoconstrictors in blood vessels, including blood vessels in the kidneys. Poor blood flow may accelerate kidney damage as the age progresses. Conversely, the androgen hormone that presents in large amounts in males can stimulate the renin-angiotensin system (RAS), causing dehydration to occur easier in males than in females. ${ }^{11,13-15}$

Dehydration is one of the causes of acute kidney dysfunction, which is usually reversible and has no long-term effects on the kidneys. However, when dehydration occurs persistently, it can cause permanent kidney damage. Kidney damage can lead to the disruption of the overall kidney function, including kidney function to concentrate urine, which then can indirectly affect the color of the urine. ${ }^{3}$ In addition to dehydration, some conditions such as hypertension, diabetes, and smoking status, can also affect kidney health. According to the National Institute of Diabetes and Digestive and Kidney Disease, hypertension is the condition of consistently rising or high blood pressure. ${ }^{16}$ Hypertension can thus damage blood vessels in the kidneys. High blood pressure in the blood vessels will cause the blood vessels to constrict so that nutrients to the kidney will be reduced and can cause kidney cells damaged and disrupt kidney function. ${ }^{17}$ However, the number of respondents with hypertension status in our study is only about $10.5 \%$. In addition to hypertension, hyperglycemia in uncontrolled diabetic patients can cause glycosylation of the basement membrane protein resulting in thickening of the glomerular basement membrane. There is an accumulation of glycoprotein-like substances in the mesangial basement membrane that may disrupt glomerular capillaries, and all of that complex processes can cause kidney damage. ${ }^{18,19}$ Kidney damage can also be caused by the nephrotoxic effect of smoking whose mechanism is not completely clear. However, some hypotheses state that smoking can cause endothelial cell dysfunction, produce oxidative stress, proinflammation, leading to glomerulosclerosis and atrophy of the kidney tubule. The adverse effects of smoking can affect the incidence of chronic renal failure in adults..$^{20}$ Dehydration can adversely affect the health conditions in general, leading to reduced concentration and work performance and thus affecting the effectiveness and work results. In addition to being detrimental at the individual level, it can also have an impact at the community level.

This study's limitations are the data obtained through questionnaires regarding water intake per day, hypertension status, smoking status, and diabetes status. Question on data on water intake per day has used glass/day as a unit, and there is no specific volume on how many $\mathrm{ml}$ of glass referred to the questionnaire. Hypertension and diabetes status are also not accompanied by the length of time they have the disease. Hypertension or diabetes may exist without the individual knows. Smoking status is not accompanied by information on smoking intensity. The category of passive smokers/non-smokers is also not further detailed. The medication used is not documented. The standard urine color chart for reference has been taken from the leaflet, making a speculative assessment due to the color change over time. Future study is needed to obtain more specific information in the questionnaire. It is also recommended to add some other variables that influence the hydration level such as body weight, fat mass in the body, physical activity performed by each subject, kidney disease status, and others.

To conclude, the majority of male respondents in our study are in severe dehydration based on urine color taken in the morning, although most of them have a habit of consuming $\geq 8$ glasses per day. They are aged 40-79 years, do not have hypertension or diabetes, and are active smokers. Therefore, it is important to educate the male workers on kidney health, the importance of adequate water intake, and the impact of dehydration on health. Moreover, forging a standard chart of urine color in the bathroom can trigger the employees to easily identify their hydration status and drink more water in case of severe dehydration.

\section{Acknowledgment}

We were grateful to the employees of $P D$ Kebersihan, Bandung, who participated in the study.

\section{References}

1. International Chair for Advanced Studies on Hydration. Human hydration [Internet]. 2016 [cited 2019 Apr 3]. Available from: http://cieah.ulpgc.es/en/main

2. Sari NA, Nindya TS. Hubungan asupan cairan, status gizi dengan status hidrasi pada pekerja di Bengkel Divisi General Engineering PT PAL Indonesia. Media Gizi Indones. 2018;12(1):47-53.

3. Roncal-Jimenez C, Lanaspa MA, Jensen T, Sanchez-Lozada LG, Johnson RJ. 
Mechanisms by which dehydration may lead to chronic kidney disease. Ann Nutr Metab. 2015;66:10-3.

4. Baron S, Courbebaisse M, Lepicard EM, Friedlander G. Assessment of hydration status in a large population. Br J Nutr. 2015;113(1):147-58.

5. Kavouras SA, Johnson EC, Bougatsas D, Arnaoutis G, Panagiotakos DB, Perrier E, et al. Validation of a urine color scale for assessment of urine osmolality in healthy children. Eur J Nutr. 2016;55(3):907-15.

6. Hagn RG, Waldréus N. An aggregate urine analysis tool to detect acute dehydration. Int J Sport Nutr Excercise Metab. 2013;23(4):303-11.

7. Biro Umum Kemkes RI. Infografis bagan warna urin [Internet]. 2018 [cited 2019 Apr 4]. Available from: http://roum. kemkes.go.id/berita/index.php

8. Kementrian Kesehatan RI. Pedoman gizi seimbang. Jakarta: Kemenkes RI; 2014. p.1-99

9. Benelam B, Wyness L. Hydration and health: A review. Nutr Bull. 2010;35(1):325.

10. Péronnet F, Mignault D, Du Souich $\mathrm{P}$, Vergne S, Bellego L Le, Jimenez L, et al. Pharmacokinetic analysis of absorption, distribution and disappearance of ingested water labeled with D20 in humans. Eur J Appl Physiol. 2012;112(6):2213-22.

11. Chmielewski P, Strzelec B, Borysławski K, Chmielowiec K, Chmielowiec J, Dąbrowski P. Effects of aging on the function of the urinary system: longitudinal changes with age in selected urine parameters in a hospitalized population of older adults. Anthropol Rev. 2016;79(3):331-45.

12. Penggalih MHST, Sofro ZM, Rizqi ER, Fajri Y. Prevalensi kasus dehidrasi pada mahasiswa Universitas Gadjah Mada. J Gizi Klin Indones. 2014;11(2):72.

13. Perinpam M, Ware EB, Smith JA, Turner ST, Kardia SLR, Lieske JC. Key influence of sex on urine volume and osmolality. Biol Sex Differ. 2016;7(1):1-8.

14. Sobamowo H, Prabhakar SS. The kidney in aging: physiological changes and pathological implications. Mol Biol Aging. 2017;146:303-40.

15. Weinstein JR, Anderson S. The aging kidney: physiological changes. Adv Chronic Kidney Dis. 2010;17(4):302-7.

16. National Institute of Diabetes and Digestive and Kidney Disease (NIDDK). High blood pressure \& kidney disease [Internet]. 2014 [cited 2019 Nov 11]. Available from: https://www.niddk.nih.gov/healthinformation/kidney-disease/high-bloodpressure

17. Bahar B, Kadrianti E, Nani. Hubungan hipertensi dengan kejadian gagal ginjal di RS Ibnu Sina Makassar periode Januari 2011-Desember 2012. Maj Kedokt Indones. 2014;4(2):163-8.

18. Sari N, Hisyam B. Hubungan antara diabetes melitus tipe II dengan kejadian gagal ginjal kronik di Rumah Sakit Pku Muhammadiyah Yogyakarta periode Januari 2011-Oktober 2012. J Kedokt dan Kesehat Indones. 2014;6(1):11-8.

19. Rivandi J, Yonata A. Hubungan diabetes melitus dengan kejadian gagal ginjal kronik. Majority. 2015;4(9):27-34.

20. Xia J, Wang L, Ma Z, Zhong L, Wang Y, Gao $\mathrm{Y}$, et al. Cigarette smoking and chronic kidney disease in the general population: A systematic review and meta-analysis of prospective cohort studies. Nephrol Dial Transplant. 2017;32(3):475-87. 